\title{
Ganciclovir Sodium
}

National Cancer Institute

\section{Source}

National Cancer Institute. Ganciclovir Sodium. NCI Thesaurus. Code C1588.

The sodium salt form of ganciclovir, a synthetic, antiviral, purine nucleoside analog with antiviral activity, especially against cytomegalovirus (CMV). Ganciclovir sodium is a prodrug that is phosphorylated and subsequently converted into its triphosphate form, the active metabolite ganciclovir-5-triphosphate (ganciclovir-TP), in the infected cells by cellular kinases. Ganciclovir-TP competes as a substrate with nucleotide triphosphates for viral DNA polymerase. Once it gets incorporated into DNA strand, it prevents further polymerization of DNA, thereby interfering with viral DNA replication. 